\title{
Preliminary estimate for reinforcement steel quantity in residential buildings
}

DOI 10.1515/otmcj-2016-0006

Received Apr 20, 2016; accepted Jul 27, 2016

\begin{abstract}
The objective of this study was to develop prediction mathematical equations to compute reinforcement steel quantity in traditional residential buildings based on 158 sets of data collected in the West Bank in Palestine. The records related to the quantities were collected from consultancy firms that provide reinforced concrete design services. The data were collected for residential buildings up to four floors. Linear regression analysis was chosen to show the correlation between the included variables. The following variables were used in the regression models: quantity of reinforcement steel (dependent variable), structural element volume (independent variable) and floor area (independent variable). Fourteen models were developed; nine models were developed to compute the quantity of reinforcement steel in different structural elements: slabs, beams, columns and footings. The other five models were used to estimate the total steel quantity in a residential building. The coefficient of multiple determination $\left(R^{2}\right)$ of the developed models ranged from 0.70 to 0.82 . This confirms a good correlation between the dependent and the independent variables. The accuracy of the developed models was tested using the mean absolute percentage error (MAPE) test. With MAPE values ranging from $21 \%$ to $36 \%$, the results compare favourably with past research that indicated that accuracy between $\pm 25 \%$ and $\pm 50 \%$ at the early stages is acceptable. The results also show that the models built on structural element size have better accuracy than the models using floor area. Such types of equations are very useful, especially in their simplicity and ability to be handled by calculators or simple computer programmes.
\end{abstract}

Keywords: reinforcement steel, quantity surveying, floor area, regression models, preliminary estimate

\footnotetext{
*Corresponding author: Ibrahim Mahamid, Civil Engineering Department, Engineering Faculty, Hail University, Hail, Saudi Arabia, E-mail:imahamid@ymail.com ori.mahamid@uoh.edu.sa
}

\section{Introduction}

The construction industry is considered to be one of the most risky and complex industries. However, the industry plays a major role in the development and achievement of society goals. It is one of the largest industries and contributes to about $10 \%$ of the gross national product in industrialized countries (Navon 2005). In Palestine, the local construction industry is one of the main economic driving sectors supporting the Palestinian national economy. However, many local construction projects report poor performance due to many causes, such as lack of labour and cost estimates, nonavailability of prices database, nonavailability of materials, excessive amendments of design and drawings as well as poor coordination among participants (Mahamid 2015). In spite of the challenges faced, the construction industry in Palestine plays a basic role in providing homes, public facilities and infrastructure for economic enterprises, in addition to its role in improving the Palestinian national economy as a whole (Enshassi et al. 2006). For example, the gross domestic capital formation in the Palestinian territories rose from US $\$ 10.8$ million to US $\$ 520.3$ million between 1968 and 1987, and this was primarily attributable to the contribution of the construction industry, which was in the range of $43 \%-82 \%$ during the same period (UN Committee on Trade and Development 1994). The Palestinian construction industry also plays a great role in the absorption of the Palestinian labour force as opposed to the manufacturing and agriculture industries. The construction industry share in the employment of the Palestinian labour force has increased continuously. To demonstrate, the volume of Palestinian workforce working in the construction industry in the Palestinian territories and Israel increased from 23,900 workers in 1970 to 97,000 workers in 1993 (Enshassi et al. 2007). Meanwhile, the Palestinian workforce in the construction industry in 2000 comprised $19.7 \%$ of the total volume of the Palestinian labour force (Palestinian Academic Society for the Study of International Affairs [PASSIA] 2002).

In most construction projects, the project must go through different phases. In general, the project life cycle 
proceeds in the following stages: from the owner's planning and budgeting phase (preliminary phase), through the design phase when the design and specifications are prepared, to the contractor selection phase (bidding phase), and through the construction stage of the projects to the handing over phase when the project is completed and turned over to the owner for use (Holm et al. 2005). The preliminary stage of the projects is very important for the owner because he/she establishes a conceptual estimate, schedule and programme. In addition to that, the owner takes the most important decision of whether to proceed with the project or not (Mahamid 2013). Therefore providing the owner with accurate information about the probable cost of the projects is critical because it affects his/her decision. In general, cost estimates consist of estimates of materials, labour and equipments. However, a good estimate depends on many factors, including a wide range of assumptions regarding the project (Jrade and Alkass 2007). Thus, estimate of required quantity of construction materials with good accuracy at the early phase of project development is crucial for accurate cost estimate.

To build a residential building, the quantities of earthwork, concrete and reinforcement steel required to complete the project need to be estimated (skeleton). Getting an accurate quantity estimate will be helpful in planning for the cost of materials and labour to build a residential building. According to Ahuja et al. (1994), estimating is the primary function of the construction industry; the accuracy of estimates starting from the early phase of a project through the tender estimate can affect the success or failure of a construction project. They also pointed out that many instances of failures of construction projects have been caused by inaccurate estimates.

In spite of the importance of prediction of needed construction materials in construction projects at the early stages, very little research has been conducted on this topic. However, a number of studies have used quantities of work items in construction projects to develop cost and time estimate models. On the basis of 286 sets of data collected in the UK, Lowe et al. (2006) developed linear regression models to predict the construction cost of buildings. They identified 41 potential independent variables, and, through the regression process, showed five significant influencing variables, such as gross internal floor area, function, duration, mechanical installations and piling.

Bell and Bozai (1987) used work item quantities per road mile to develop multiple linear regression models for the preliminary cost estimation to be used by the Alabama
Highway Department for long-range cost forecasting. Mahamid (2011) used bid quantities of road construction projects to develop cost prediction models in road construction projects in Palestine. Abu Hammad et al. (2008) developed regression prediction models for building construction cost and duration in Jordan using real data of 140 projects.

This study aims at developing prediction models to compute reinforcement steel quantity in traditional residential buildings based on 158 sets of data collected in the West Bank in Palestine. Such types of models are very useful, especially in their simplicity and ability to be handled by a calculator or a simple computer programme. It has good benefit in estimating project material quantities at early stages of the project because the required input could be extracted easily from the sketches or scope definition of the project.

\section{Research method}

Figure 1 shows the method used to achieve the study objective. The method can be summarized as follows:

1. First of all, the study objective is defined as follows: to develop simple mathematical models to compute the quantity of reinforcement steel needed for different structural elements of residential buildings.

2. To achieve the study objective, 158 sets of data were collected in the West Bank in Palestine. The projects were implemented over the years 2012-2015. The records on quantities were collected from consultancy firms that provide reinforced concrete design services. The data were collected for residential buildings rising up to four floors. This is because most of the residential buildings in Palestine consist of four floors or less. Consideration was taken to have approximately equal number of projects according to number of floors: one floor (40 projects), two floors ( 45 projects), three floors (38 projects) and four floors (35 projects).

3. The variables to be included in the mathematical models were defined: quantity of reinforcement steel (dependent variable), element volume (independent variable) and floor area (independent variable).

4. Linear regression was selected to be used as a tool to show the correlation between the included variables. Excel statistical tools were used to perform regression analyses and to test the significance of the model.

5. The accuracy of the developed models was tested using the mean absolute percentage error (MAPE). 


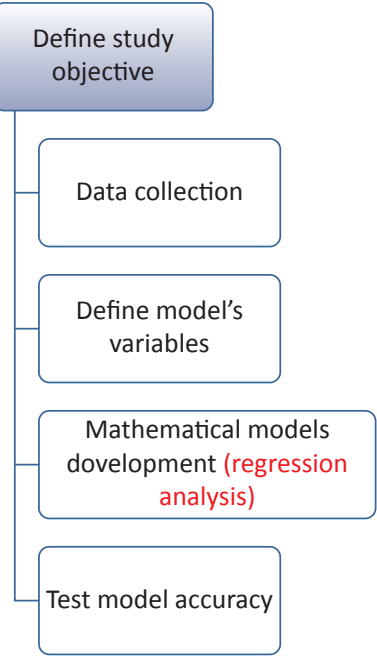

Fig. 1: Research method.

Tab. 1: Variables included in the models.

\begin{tabular}{ll}
\hline Models variables & Type of variable \\
\hline$Y=$ reinforcement steel quantity, in & Dependent variable \\
kilograms & \\
$X_{1}=$ flat slab volume, in cubic metres & Independent variable \\
(for flat slab with beams) & \\
$X_{2}=$ flat slab volume, in cubic metres & Independent variable \\
(for flat slab without beams) & \\
$X_{3}=$ hollow block slab volume, in & Independent variable \\
cubic metres (with hidden beams) & \\
$X_{4}=$ hollow block slab volume, in & Independent variable \\
cubic metres (with drop beams) & \\
$X_{5}=$ solid slab volume, in cubic metres & Independent variable \\
(with drop beams) & \\
$X_{6}=$ isolated footing volume, in & Independent variable \\
cubic metres & \\
$X_{7}=$ strip footing volume, in cubic metres & Independent variable \\
$X_{8}=$ column volume, in cubic metres & Independent variable \\
$X_{9}=$ beam volume, in cubic metres & Independent variable \\
$X_{10}, X_{11}, X_{11}, X_{13}, X_{14}=$ floor area in square & Independent variable \\
metres (based on number of floors) & \\
\hline
\end{tabular}

\section{Results and discussion}

\subsection{Quantity of steel as a function of structural element volume}

Once a set of probable predictors were identified (Table 1), nine mathematical models were developed using the linear regression technique (Table 2). These models can be used to determine the quantity of reinforcement steel for each structural element in residential buildings at the early stages of the project. The structural elements included were flat slab (with beams and without beams), hollow block slab (with drop beams or with hidden beams), solid slab, beam, column, isolated footing and strip footing. The models used quantity of reinforcement steel as the dependent variable and element volume as the independent variable.

With $R^{2}$ value $>0.70$ and $P$-value $<0.05$, the results show a good correlation between dependent and independent variables and confirmed the statistical significance of the models at a significance level of 0.05. The developed models are of the following form:

$$
Y_{\mathrm{i}}=\mathrm{a} X_{\mathrm{i}}
$$

where $Y_{\mathrm{i}}$ is the reinforcement steel quantity for element $i$ $(\mathrm{kg})$ and $X_{\mathrm{i}}$ is the volume of element $i\left(\mathrm{~m}^{3}\right)$.

The following examples illustrate how to estimate the quantity of reinforcement steel for any structural element of residential buildings at the early stages of the projects.

Example 1: For a $100 \mathrm{~m}^{2}$ solid slab with thickness = $12 \mathrm{~cm}$, estimate the required quantity of reinforcement steel in tons?

Solution:

- $\quad$ Slab volume $=100 \times 0.12 \times 12 \mathrm{~m}^{3}$

Reinforcement steel quantity for the slab $=102.36 \times$ $12=1,228 \mathrm{~kg}=1.228$ tons

Example 2: For a $2 \mathrm{~m} \times 1.5 \mathrm{~m} \times 0.5 \mathrm{~m}$ isolated footing, estimate the reinforcement steel quantity in tons?

Solution:

- Footing volume $=2 \times 1.5 \times 0.5=1.5 \mathrm{~m}^{3}$

Footing reinforcement steel quantity $=75.16 \times 1.5=$ $112.74 \mathrm{~kg}=0.113$ tons

\subsection{Steel quantity as a function of floor area}

A regression model that describes the total quantity of reinforcement steel for a residential building as a function of floor area is developed. The coefficient of determination $R^{2}$ for the developed equation is 0.56 . The results of the regression statistics for the developed model are shown in Table 3. The developed model is represented as follows:

$$
Y_{10}=31.24 X_{10} \quad \text { Model } 10
$$

where $Y_{10}$ is the total quantity of reinforcement steel for residential building $(\mathrm{kg})$ and $X_{10}$ is the total floor area $\left(\mathrm{m}^{2}\right)$.

It can be seen that Model 10 has low $R^{2}$ value. Therefore, other models were developed taking into consideration the number of floors in the residential building. The results are shown in Table 4 . With $R^{2}>0.7$, the results 
Tab. 2: The developed models (steel quantity as a function of structural element volume).

\begin{tabular}{|c|c|c|c|c|}
\hline Model no. & Structural element & $\begin{array}{l}\text { Range of reinforcement } \\
\text { steel quantity } \\
\text { ( } \mathrm{kg} / \mathrm{m}^{3} \text { of element } \\
\text { volume) }\end{array}$ & Regression model & Notes \\
\hline 1 & Flat slab with beams & $80-100$ & $\begin{array}{l}Y_{1}=92.25 X_{1} \\
\left(R^{2}=0.77, P=0.00\right)\end{array}$ & Average slab thickness $=17 \mathrm{~cm}$ \\
\hline 2 & Flat slab without beams & $130-150$ & $\begin{array}{l}Y_{2}=139.52 X_{2} \\
\left(R^{2}=0.74, P=0.00\right)\end{array}$ & Average slab thickness $=20 \mathrm{~cm}$ \\
\hline 3 & $\begin{array}{l}\text { Hollow block slab (with hidden } \\
\text { beams) }\end{array}$ & $110-130$ & $\begin{array}{l}Y_{3}=122.36 X_{3} \\
\left(R^{2}=0.80, P=0.00\right)\end{array}$ & Average slab thickness $=27 \mathrm{~cm}$ \\
\hline 4 & $\begin{array}{l}\text { Hollow block slab (with drop } \\
\text { beams) }\end{array}$ & $80-100$ & $\begin{array}{l}Y_{4}=88.96 X_{4} \\
\left(R^{2}=0.80, P=0.00\right)\end{array}$ & Average slab thickness $=27 \mathrm{~cm}$ \\
\hline 5 & Solid slab (with drop beams) & $90-110$ & $\begin{array}{l}Y_{5}=102.36 X_{5} \\
\left(R^{2}=0.82, P=0.00\right)\end{array}$ & Average slab thickness $=14 \mathrm{~cm}$ \\
\hline 6 & Isolated footings & $70-90$ & $\begin{array}{l}Y_{6}=75.16 X_{6} \\
\left(R^{2}=0.76, P=0.000006\right)\end{array}$ & \\
\hline 7 & Strip footings & $80-100$ & $\begin{array}{l}Y_{7}=90.58 X_{7} \\
\left(R^{2}=0.78, P=0.00\right)\end{array}$ & \\
\hline 8 & Columns & $90-140$ & $\begin{array}{l}Y_{8}=124.13 X_{8} \\
\left(R^{2}=0.77, P=0.00\right)\end{array}$ & \\
\hline 9 & Beams & $70-120$ & $\begin{array}{l}Y_{9}=100.42 X_{9} \\
\left(R^{2}=0.76, P=0.00\right)\end{array}$ & \\
\hline
\end{tabular}

Tab. 3: Results of multiple regression for total steel quantity and floor area.

\begin{tabular}{lclll}
\hline Regression statistics & Variables & Coefficient & P-value \\
\hline$R^{2}$ & 0.56 & Floor area $\left(\mathrm{m}^{2}\right)$ & 31.24 & $9.43 \mathrm{E}-05$ \\
\cline { 4 - 5 } Observations & 158.0 & & \\
$F$ & 120.5 & & & \\
\hline
\end{tabular}

Tab. 4: Regression models for total steel quantity and floor area based on number of building floors.

\begin{tabular}{llll}
\hline Model no. & Regression model & Notes & R2, P-value \\
\hline 11 & $Y_{10}=40.36 X_{11}$ & One floor building & $0.72,0.00$ \\
12 & $Y_{10}=35.76 X_{12}$ & Two-floor building & $0.73,0.00$ \\
13 & $Y_{10}=33.73 X_{13}$ & Three-floor building & $0.71,0.00$ \\
14 & $Y_{10}=31.25 X_{14}$ & Four-floor building & $0.69,0.00$ \\
\hline
\end{tabular}

Tab. 5: Examples to illustrate the models in Table 4.

\begin{tabular}{llllll}
\hline $\begin{array}{l}\text { Example } \\
\text { no. }\end{array}$ & $\begin{array}{l}\text { Floor } \\
\text { area } \\
\left(\mathbf{m}^{2}\right)\end{array}$ & $\begin{array}{l}\text { No. } \\
\text { of } \\
\text { floors }\end{array}$ & $\begin{array}{l}\text { Total } \\
\text { area }\end{array}$ & $\begin{array}{l}\text { Model } \\
\text { used }\end{array}$ & $\begin{array}{l}\text { Steel } \\
\text { quantity } \\
(\mathbf{k g})\end{array}$ \\
\hline 1 & 150 & 1 & 150 & 11 & $40.36 \times 150=6,054$ \\
2 & 150 & 2 & 300 & 12 & $35.76 \times 300=10,728$ \\
3 & 150 & 3 & 450 & 13 & $33.73 \times 450=15,178.5$ \\
4 & 150 & 4 & 600 & 14 & $31.25 \times 600=18,750$ \\
\hline
\end{tabular}

indicate better correlation between dependent and independent variables.

Table 5 illustrates some examples to estimate the total reinforcement steel quantity for residential buildings.

\section{Testing the accuracy of the developed models}

The MAPE was used to measure the accuracy of the developed models. The following formula was used to compute the MAPE (Lowe et al. 2006):

$$
\operatorname{MAPE}=\left(\frac{1}{n}\right) \sum_{i=1}^{n}\left|\frac{\left(A_{i}-F_{i}\right)}{A_{i}}\right|
$$

where $A_{\mathrm{i}}$ is the actual value, $F_{\mathrm{i}}$ is the forecast value and $n$ is the number of fitted points.

Table 6 shows the regression models developed in the study. Fourteen models were developed to estimate the quantity of reinforcement steel in residential buildings; Models 1 to 9 can be used to estimate the quantity of reinforcement steel in structural elements (i.e. slab, beam, column, footing, $1 / 4$ etc.) based on element volume, while Models 10 to 14 can be used to estimate the total quantity of reinforcement steel in residential buildings based on floor area.

It should be noted that in the very early stages, the size of the structural element is not available, meaning 
Tab. 6: Summary of the developed regression models.

\begin{tabular}{ll}
\hline Model no. & Regression model \\
\hline 1 & $Y_{1}=92.25 X_{1}$ \\
2 & $Y_{2}=139.52 X_{2}$ \\
3 & $Y_{3}=122.36 X_{3}$ \\
4 & $Y_{4}=88.96 X_{4}$ \\
5 & $Y_{5}=102.36 X_{5}$ \\
6 & $Y_{6}=75.16 X_{6}$ \\
7 & $Y_{7}=90.58 X_{7}$ \\
8 & $Y_{8}=124.13 X_{8}$ \\
9 & $Y_{9}=100.42 X_{9}$ \\
10 & $Y_{10}=31.24 X_{10}$ \\
11 & $Y_{10}=40.36 X_{11}$ \\
12 & $Y_{10}=35.76 X_{12}$ \\
13 & $Y_{10}=33.73 X_{13}$ \\
14 & $Y_{10}=31.25 X_{14}$ \\
\hline
\end{tabular}

where

$Y_{i}$ is the reinforcement steel quantity in element $i(\mathrm{~kg})$ ( $i$ ranges from 1 to 9 ).

$Y_{10}$ is the total quantity of reinforcement steel in residential buildings $(\mathrm{kg}$ ) (for buildings up to four floors).

$X_{1}$ is the flat slab volume $\left(\mathrm{m}^{3}\right)$ (for flat slab with beams).

$X_{2}$ is the flat slab volume $\left(\mathrm{m}^{3}\right)$ (for flat slab without beams).

$X_{3}$ is the hollow block slab volume $\left(\mathrm{m}^{3}\right)$ (with hidden beams).

$X_{4}$ is the hollow block slab volume $\left(\mathrm{m}^{3}\right)$ (with drop beams).

$X_{5}$ is the solid slab volume $\left(\mathrm{m}^{3}\right)$ (with drop beams).

$X_{6}$ is the isolated footing volume $\left(\mathrm{m}^{3}\right)$.

$X_{7}$ is the strip footing volume $\left(\mathrm{m}^{3}\right)$.

$X_{8}$ is the column volume $\left(\mathrm{m}^{3}\right)$.

$X_{9}$ is the beam volume $\left(\mathrm{m}^{3}\right)$.

$X_{10}$ is the floor area $\left(\mathrm{m}^{2}\right)$.

$X_{11}$ is the floor area $\left(\mathrm{m}^{2}\right)$ (one-floor building).

$X_{12}$ is the floor area $\left(\mathrm{m}^{2}\right)$ (two-floor building).

$X_{13}$ is the floor area $\left(\mathrm{m}^{2}\right)$ (three-floor building).

$X_{14}$ is the floor area $\left(\mathrm{m}^{2}\right)$ (four-floor building).

that the estimating models using floor area (Models 10 to 14) are more fit to be used. Later, when the element size is available, Models 1 to 9 can be used.

The MAPE results are shown in Table 7. The results indicate that the MAPE values of the developed models range from $21 \%$ to $36 \%$, which compares favourably with past reports that indicated that accuracy between $\pm 25 \%$ and $\pm 50 \%$ at the early stages is acceptable (Lowe et al. 2006; Schexnayder and Mayo 2003; Sodikov 2005). The results also show that the models built on structural element size have better accuracy than the models built on floor area.

\section{Conclusion}

This study aims at developing prediction regression models to compute reinforcement steel quantity in traditional residential buildings based on 158 sets of data collected in the
Tab. 7: MAPE results for the developed regression models.

\begin{tabular}{ll}
\hline Model no. & MAPE (\%) \\
\hline 1 & 24.31 \\
2 & 26.13 \\
3 & 21.89 \\
4 & 22.21 \\
5 & 21.81 \\
6 & 25.12 \\
7 & 23.58 \\
8 & 23.97 \\
9 & 24.83 \\
10 & 36.13 \\
11 & 28.12 \\
12 & 27.30 \\
13 & 29.14 \\
14 & 30.16 \\
\hline
\end{tabular}

West Bank in Palestine. Fourteen models were developed. Nine models could be used to compute the quantity of reinforcement steel in different structural elements: slabs, beams, columns and footings. The other five models could be used to estimate the total steel quantity in residential buildings. The coefficient of determination $R^{2}$ for the developed models ranges from 0.70 to 0.82 . This indicates that the relationship between the dependent and independent variables of the developed models is good and the predicted values from a forecast model fit with the real-life data. The accuracy of the developed models was tested using MAPE. MAPE values ranging from $21 \%$ to $36 \%$ compare favourably with past research that indicated that accuracy between $\pm 25 \%$ and $\pm 50 \%$ at the early stages is acceptable. The results also show that the models built on structural element size have better accuracy than the models built on floor area. Such types of equations are very useful, especially in their simplicity and ability to be handled by a calculator or a simple computer programme. It has good benefit in estimating project material quantities at early stages of the project because the required input could be extracted easily from the sketches or the scope definition of the project.

It must be remembered that an estimated quantity is not an exact number, but it is an opinion of the probable quantity. However, the accurate quantity could be calculated using the design documents and specifications.

\section{References}

Abu Hammad, A., Alhaj Ali, S., Sweis, G., \& Bashir, A. (2008). Prediction model for construction cost and duration in Jordan. Jordan Journal of Civil Engineering, 2(3), 250-266. 
Ahuja, H. N., Dozzi, S. P., \& Abourisk, S. M. (1994). Project Management Techniques in Planning and Controlling Construction Projects. John Wiley and Sons, Inc., New York.

Bell, L. C., \& Bozai, G. A. (1987). Preliminary cost estimating for highway construction projects. AACE Transactions, C.6.1-C.6.4.

Enshassi, A., Hallaq, K., \& Mohamed, S. (2006). Causes of contractor's business failure in developing countries: the case of Palestine. Journal of Construction in Developing Countries, 11(2), 1-14.

Enshassi, A., Mohamed, S., \& Madi, I. (2007). Contractors' perspectives towards factors affecting cost estimation in Palestine. Jordan Journal of Civil Engineering, 1(2), 186-193.

Holm, L., Schaufelberger, J., Griffin, D., \& Cole, T. (2005). Construction Cost Estimating: Process and Practices. Pearson Education, Inc., New Jersey.

Jrade, A., \& Alkass, S. (2007). Computer-integrated system for estimating the costs of building projects. Journal of Architectural Engineering, 13(4), 205-223.

Lowe, D. J., Emsley, M. W., \& Harding, A. (2006). Predicting construction cost using multiple regression techniques. Journal of Construction Engineering and Management. 132(7), pp. 750-758.

Mahamid, I. (2011). Early cost estimating for road construction projects using multiple regression techniques. Australasian Journal of Construction Economics and Building, 11(4), pp. 78-101.
Mahamid, I. (2013). Frequency of time overrun causes in road construction in Palestine: Contractors' view. Organization, Technology and Management in Construction: An International Journal, 5(1), pp. 720-729.

Mahamid, I. (2015). Factors affecting cost estimating accuracy: evidence from Palestinian construction projects. International Journal of Management Science and Engineering Management, 10(2), pp. 117-125.

Navon, R. (2005). Automated project performance control of construction projects. Automation in Construction, 14, pp. 467-476.

Palestinian Academic Society for the Study of International Affairs (PASSIA). (2002). Available at http://www.passia.org/.

Schexnayder, C. J., \& Mayo, R. E. (2003). Construction Management Fundamentals. McGraw-Hill Higher Education, Boston, MA.

Sodikov, J. (2005). Cost estimation of highway projects in developing country: artificial neural network approach. Journal of the Eastern Asia Society for Transportation Studies, 6, pp. 1036-1047.

United Nation (UN) Committee on Trade and Development. (1994). Prospect for Sustained Development of the Palestinian Economy in the West Bank and Gaza, 1990 to 2010: A Qualitative Framework. UN, Geneva. 